\title{
Inggit Garnasih and Her Big Role as Soekarno's Wife
}

\author{
Devina Widya Putri
}

\begin{abstract}
There is a quote which said, "For every man's success, there must be a great woman behind it". And the story of life of Inggit Garnasih proves it. Inggit was the second wife of Indonesia's first president, Ir. Soekarno. Soekarno had many wives in his lifetime, but Inggit was the only wife who accompanied Soekarno on his hard time, only took him to the gate of glory without tasting the glory itself, and still loved him even though he left her to marry another woman, who is their own foster child, Fatimah. She is the one who always strengthen Soekarno through many obstacles during his struggle to realize Indonesia's independence. Although she has never been mentioned as hero, what she has done, which is being a faithful and strong-hearted wife for Soekarno, has been one of great contributions for Indonesia's independence.
\end{abstract}

Index Terms - Colonial period, history, wife, woman.

\section{INTRODUCTION}

History left many factual impression how women have important role. Even though hadith said that women are the pillar of the state. Deeper review about this shows us that women are able to become a part of contribution in civilization's development [1].

History speaks through facts that deliver volumes of study for human about women who sometimes disastrous, but on the other side is able to be the sowers of love. By studying women's history deeply, laws of love that haven't been discovered will be found. In every levels of life, history always offers many kinds of meaning and wisdom [1].

It's not right to say that history is a bunk. There are many historical messages which can be evocative power in growing a nation if we examine the role of women in history carefully. Women not only have big role in the domestic sector, but also in the public world; women can be the inspiration and strength for the fighters [1].

History has proven that woman played important role in the building of a civilization, although some of the stories about it are painful. Hendrasmara in Menelusuri Jejak Marilyn Monroe said that since thousands years ago women and power can't be separated from each other [2] World leaders can't be separated from women's love and support, such as their mother's or their wife's. We can see this from the story of Julius Caesar and Cleopatra, Louis XVI and Marie Antoinette, or the story of Napoleon, Josephine and Marie Louise. The important role of wife for her family, especially for her husband, also happened in Indonesia at

Manuscript received January 10, 2014; revised March 13, 2014.

Devina Widya Putri is with the University of Indonesia (e-mail: devinawp@gmail.com). the colonialism period.

During the colonial period, Indonesian people did anything they could to get independence. They negotiated, made agreement, and even rebelled by war. Those independence warriors passed hard times during the struggle.

Women, who are sometimes seen as a pernicious, are able to appear as being full of love and tenderness. Anis Matta in Nafas Cinta Sang Kekasih said that women can be a psycho-historical power for warriors [3]. The nation's leaders could not be separated from the love and support of the women as a source of energy to struggle [1].

We can see this happened to important men at that period. Agus Salim, who really loves Zaitun Nahar, Bung Tomo's love to Sulistina, and one of legendary love, H.O.S. Tjokroaminoto to Suharsikin. Beside those examples, still there are many women who played big role behind their husbands'. Those women did anything behind the scene, and as time went by, their kindness lost in time.

One of women who have made history for the nation of Indonesia in her time but her name is timeless is Inggit Garnasih. Her position as Soekarno's wife (the second one after Oetari), became inspiration source in his political struggle. [1] Even half of Soekarno's achievement can be deposited in Inggit Garnasih's account in "Bank Services Nationalism of Indonesia" [4].

Inggit was not only a wife who can take Soekarno to the glory as nation's leader. More than that, Inggit was figure of mother, lover and also friend who accompanied Soekarno selfless. Inggit Garnasih for young Soekarno embodies the love of a mother which he never experienced before. She was Soekarno's one and only lover who loved him not because of his wealth and power, who gave without asked, and the only one who accompany Soekarno in poverty and deprivation [4].

John Legge said that on the crucial years, during 1920, Soekarno appeared confidently with Inggit's accompany. Inggit supported Soekarno emotionally and in Soekarno's partners' memory at that time, Inggit's support was really important for him [5].

For Soekarno, Inggit was not only "stick" that held his soul. More than that, Inggit was a power that couldn't be found anywhere else.

Many times Soekarno fell, many times Inggit helped him to come back and struggle again. The love power of Inggit helped Soekarno to stand tall. On that crucial year, Soekarno became political actor, topic among Dutch East Indies society, and became a great orator who known as "the lion of the podium" [1].

\section{MAIN BODY}

\section{A. Ir. Soekarno, Father of the Nation}

Everyone in Indonesia surely knows who Ir. Soekarno is. 
He is one of people who had important role in Indonesia's independence.

Soekarno was born in Surabaya, a city in eastern Java Island, Indonesia, on June 6, 1901. He was born from a noble family [6]. The family's socio-economic condition is somewhat better than others' [7].

Paul van't Veer, a Dutch journalist, on of people who write the biography of Soekarno, opened his writing with these words: "Anyone who wants to be a figure like Soekarno must firstly chose their date of birth carefully, and June 1910 is not a bad choice." [8] Soekarno, in his biography that written by Cindy Adams, admitted it. "My birthday is double six. June six. It's my supreme good fortune to have been born under Gemini, the sign of twins," he said. Soekarno's mother, Ida Ayu Nyoman Rai, once told him when he was 2 years old, "Son, you are looking at the sunrise. And you, my son, will be a man of glory, a great leader of his people, because your mother gave birth to you at dawn. We Javanese believe that one born at the moment of sunrise is predestined. Never, never forget you are a child of the dawn." With Soekarno, it wasn't only the dawn of a new day, but also a dawn of a new century. When he was born, Mount Kelud, a nearby volcano, was also erupted [9]. All the signs as if to say that Soekarno's birth was the birth of great person for the country.

And the signs were right. Soekarno became one of important people for Indonesia's independence. He's a hero for his nation. Being a hero, he was not participating in war, he was not raising arms against the imperialist. Soekarno fight for his country through oration, discussion, writing, and anything else he could do by his thinking.

Didn't stop there, Soekarno was also the person who proclaim Indonesia's independence on August 17, 1945. He became Indonesia's first president and became the one who raised Indonesia on its first decade as independence country. Even though Soekarno did many great things for the nation, he didn't do it by himself, but with help and support from his partners and family.

\section{B. Soekarno's Love Journey}

Don Juan is a famous fiction figure in Spain and Italy as the title of a man who can easily conquer woman. Some people sometimes assume Soekarno as Indonesia's Don Juan. Besides Inggit, Soekarno has had 8 more women who are considered as his lawful wives. Even though Soekarno had many wives, Inggit still became irreplaceable queen of his body and soul.

Inggit was different from Soekarno's first wife, Siti Oetari Tjokroaminoto, who was known as daughter of Javanese noble, leader of Sarekat Islam, H.O.S. Tjokroaminoto [1].

Inggit, who was Soekarno's second wife, was also not the same with the third one, Fatmawati. Fatma was a daughter of Hasan Din, a figure in Muhammadiyah in Bengkulu [1].

Inggit, when she married with Soekarno, was a widow. It's the same as Soekarno's fourth wife, Hartini. One thing that made it different was Hartini was widow of a pilot of country's plane, Sudowo, while Inggit was ex-wife of Haji Sanusi, a merchant who was active in Sarekat Islam organization in Bandung [1].

Inggit was different from Naoko Meimoto, also known as
Ratnasari Dewi, a Japanese woman, who was another wife of Soekarno. She was known as night club girl in Café Copacabana, Tokyo, who has good physical beauty. Besides that, Ratnasari Dewi was also friendly and passionate in front of Soekarno's children [1].

Physically, Inggit was also beautiful. One thing that made her different was Inggit not only had physical beauty but also maturity. It can't be denied that besides physical beauty Soekarno, as politician, also needed maturity in her wife [1].

As a comparison, Inggit's beauty was different with Haryati. Haryati was ex-dancer in palace and Secretariat of State in Art sector, who was married with Soekarno [10].

Haryati didn't leave so much mark for history of Indonesia. Haryati had only a role as a wife, not as spiritual supporter during struggle and obstacles like what Inggit had given to Soekarno. Haryati actually much guided by Soekarno [1].

The next one is Yurike Sanger. Compared to Yuri, Inggit was so much more mature in life. Yurike Sanger was from Poso. Her meeting with Soekarno happened when she was on the $2^{\text {nd }}$ grade of high school and became member of Barisan Bhineka Tunggal Ika when Soekarno came to Poso. Soekarno and Yuri divorced naturally when Soekarno passed away [1].

Yurike Sanger was not much different with Kartini Manopo. She was the painting model of Basuki Abdullah. There was no lasting impression. At first, Soekarno only saw Kartini's face through the painting. Their meeting happened when Kartini worked as stewardess who accompanied Soekarno's flight to Surabaya. The same as Yurike, Kartini and Soekarno's marriage ended naturally when Soekarno passed away [1].

Soekarno's last and youngest wife named Heldy Djafar. Heldy was one of Soekarno's wives who wasn't exposed too much. Document that tells about Soekarno's life journey with Heldy was almost never found. Heldy hid her marriage with Soekarno for 36 years. Heldy hold the record of age difference among Soekarno's wives. When she married with Soekarno on 1966, their age difference was 48 years [1].

Shades of Soekarno's love with Fatma, Dewi, Haryati, Yurike, Kartini Manopo or Heldy seemed very serene and imprint. It's different when Soekarno lived with Inggit [1].

Inggit lived with Soekarno's love which was full of struggle and sacrifice, not the tender and glamour one. Inggit never felt be in love with silk kebaya or riding car. The moment they rode car together were only in sake of party struggle [1].

Soekarno can easily read the heart of women that he loved. He also had different nickname for every wife. He called Oetari with Lak, Inggit with Enung, Fatma with Sayang, Hartini and Kartini with Tien, Haryati with Wong Ayuku, Yurike with Yuri sayang and Heldy, the youngest one, with Dik Heldy [1].

Explanation about Soekarno's wives above hopefully can be the start point to know Inggit deeper. By reading about Soekarno's wife one by one, it can be understood the comparison of Inggit with other wives. This is not intended to find the lacks, but merely to give more knowledge.

\section{Inggit Garnasih}

Inggit Garnasih was born in Bandung, West Java on 
February 17, 1888 with name Garnasih. Her name, Garnasih, stands for "Hegar Asih". Hegar means freshness livens up and Asih means affection [11].

The name "Inggit" has its own story. The word "Inggit" comes from money currency, one ringgit which is in Indonesia called "seringgit". At that time, one ringgit had big value [1].

Since she was child, Inggit became a lovable figure among her friends. And when she was a young girl, she was the most beautiful one among her friends. The young man rounded her like a beautiful flower. Among them revolved words that getting smile from Garnasih was the same as getting money one ringgit [1].

At that time, because of her beauty and kindness, many young men liked her. That feeling was expressed by giving her, directly or not, money as much as one ringgit. From that time, Garnasih called as "Si Inggit" and she was known as Inggit Garnasih [11].

Inggit was born from an ordinary family who didn't have important role. Her father's name was Ardjipan and her mother's was Amsi. Both of them, before her father passed away, were farmers. Inggit had two siblings, Natadisastra and Murtasih. Inggit lived her life simply, even when she had been married with Nata Atmadja, Sanusi and Soekarno [1].

On 1900, when Inggit was still 12 years old, she started marriage life with a Holand's Corporal Resident named Nata Atmadja. This marriage wasn't long lasted, only four years and they separated. Unfortunately, on the same year, Inggit's father also passed away [1].

After divorced with Nata Atmadja, Inggit married Haji Sanusi, a merchant who was involved in Sarekat Islam, a well-known Islam organization in Indonesia on that period. Because of Sanusi's activities and influence in Sarekat Islam, Inggit learnt a lot about political condition in Indonesia. Inggit also had an opportunity to be committee of Sarekat Islam's first congress in Bandung on 1916 and met activists like H.O.S. Tjokroaminoto and Agus Salim [1].

Inggit only got education in Madrasah Ibtidaiyah, an Islamic school whose level was the same as elementary school. This level of education was good enough for local woman on the colonialism period. Even though her education level wasn't high, she was very kind-hearted and has great strength and courage [4].

\section{Inggit Garnasih as Soekarno's Wife}

On the first time Soekarno and Inggit met, both of them have had their own wife and husband. Bandung on 1921 gave different feeling for Haji Sanusi, especially Inggit, who was none other than his wife. A letter came from H.O.S. Tjokroaminoto in Surabaya, told them that his daughter, Siti Oetari, and his son in law, Soekarno, would be at Bandung soon [1].

Their coming, especially Soekarno, was for continuing Soekarno study in Technische Hooge Schhool, a technical college in Bandung. In the letter, Tjokroaminoto asked Sanusi and his family for help seeking boarding house for Soekarno and Oetari in Bandung. At that time, Soekarno was the selected student in THS and was included smartest local student in Hogere Burger School (HBS), the same as high school at that time. Moreover, student status at that era was still upheld. Because Sanusi couldn't find appropriate boarding house, he decided to let Soekarno and Oetari stay at his house with his family [4].

Love comes uninvited. This was what happened to Soekarno and Inggit. Since their first meeting, Inggit had hidden ravishment to the young Soekarno. Fortunately, Inggit's feeling wasn't the unrequited one. For Soekarno, Inggit looked beautiful, mature, with unforgettable smile and speech. They fell in love, even at that time they had their own wife and husband [1].

As time went by, Soekarno and Inggit's togetherness became tighter. Unfortunately, that made gap of communication between Inggit and Sanusi. Since Soekarno's coming in Sanusi's house, the house became crowded by young men who were Soekarno's friends. They liked politics and had same vision to realize independence. This made Inggit became busier because she had to serve them with food and drink in discussion that held there. At that time, Inggit started to find another way to collect money, because the cost of the discussion wasn't given by Sanusi. Inggit never complain about the money [4].

One thing that disturbed her was Sanusi who usually went at night, and came back in the morning, to do gambling and billiard. Soekarno didn't take care of this problem too much because he faced the same problem with his housewifery. Since got married, Soekarno still assume Oetari as his sister, not wife. This was caused by Oetari who was still young and didn't give him his needs as husband [1].

On 1923, Soekarno divorced Oetari and gave her back to her parents when they were in Surabaya. After that, Soekarno went back to Bandung to see Inggit. Not long after, Sanusi and Inggit talked together about the problem in their housewifery. At the end, on the same year, he divorced Inggit, and let her to marry and accompany Soekarno. [4]

March 24, 1923 became important date for Soekarno and Inggit, who has 12 years age difference with Inggit was the older one. They got married and started to live together as husband and wife. Sanusi as Inggit's ex-husband also helped them to prepare the wedding [1].

Inggit realized that Soekarno was just a student, a man without earnings. Soekarno needed money for his study and for his political activity, but he couldn't earn it. To solve this problem, Inggit, as a wife, not only did housework, but also earned money for family's daily need. Inggit sold powder and herbal drink which were made by her. She used to do it when she was still Haji Sanusi's wife to get additional money, which was not too much. But, when she was Soekarno's wife, what she did was being the main income for her family [4].

After 3 years marriage life, Inggit hadn't born a child. Because of his strong desire to have a child, Inggit adopted her sister, Murtasi's, daughter. The baby's name was Arawati, but because she often got sick, Soekarno changed her name became Ratna Juami. Omi, how she used to be called, was born on May 4, 1923, and brought to Inggit's house when her age was still 40 days. Omi's presence became new happiness for Soekarno and Inggit. They both loved her and their house was no longer lonesome [1].

On 1926, Soekarno graduated from THS. Inggit was very glad and happy for that. Inggit had proven that she was 
successful became a good wife for Soekarno. Inggit felt that every sacrifice, hard work, and prayer she had done had been granted by God [4].

Soekarno was offered job as lecture assistant in THS, but he refused it. He didn't want to work with or for Dutch. So then he, with his partner, Anwari set up a bureau of engineering on 1926. Unfortunately, the bureau didn't work well because their focus was fully on political activities to realize Indonesia's independence. They closed the bureau and set up a study club. On its development, the study club became political association and developed to party. On June 4, 1927, Soekarno established Partai Nasional Indonesia (PNI) which had goal to realize Indonesia's independence. Thanks to Soekarno's struggle and Inggit's support, PNI became front line party on 1920s [1].

Inggit became busier because of Soekarno's activities in party. Inggit accompanied him and also struggled to develop PNI. For Inggit, develop PNI wasn't easy. Even though Soekarno had good ability to persuade people, the people of party was still not many. Inggit also became Sundanese translator for Soekarno, because of people in Bandung usually use Sunda language in their daily life. Besides that, Inggit never forgot to prepare all Soekarno's needs, include food, drink, and even herbal drink to keep him healthy [4].

Unfortunately, PNI movement was assumed as danger by Colonial Government. On December 29, 1929 Soekarnno and his partners were arrested. Soekarno was threatened to 4 years imprisonment. This made people in PNI spread without control. For 8 months, Soekarno was imprisoned in Banceuy prison. The court was deliberately protracted to kill his spirit. He was weakened. This was the start of struggling life that they had to face [1].

Since Inggit visited him in prison, Soekarno became stronger. Inggit tried not to cry. Inggit knew that she couldn't help him through dangerous way, like politics or justice. So then, Inggit did it in other way [4].

Inggit brought him food and tucked money in it, so then Soekarno could have newspaper and special right by giving the money to the warder as bribe. By the special right, Soekarno could read some books from library. One day, when Soekarno needed Mr. Sartono's books in prison, Inggit was willing to do fasting for 3 days, so she could bring the books to the prison without the guard knowing. With those books, Soekarno wrote a legendary writing known as Indonesia Menggugat [4].

Soekarno was moved to Sukamiskin prison, about 15 kilometers from Bandung, after officially sentenced to 4 years imprisonment in court. In this prison, Soekarno felt how suffering to be a prisoner. Soekarno got special right but he was placed away from his partners, so they couldn't contact each other. Condition in Sukamiskin precisely incriminated Soekarno physically and mentally [1].

One month after Soekarno moved to Sukamiskin, Inggit and Omi visited him and brought him his favorite food and cookies. Inggit never showed sadness or depression. Love that she gave to Soekarno became power that strengthened him and his dreams, even in his worst condition in Sukamiskin prison [4].

Every week, Inggit always visited Soekarno in Sukamiskin. She wanted to always bring their beloved daughter, but because of financial trouble that made her must go there on foot for about 20 kilometers, Inggit only brought Omi there when she had money to ride vehicle. Before went there, Inggit collect money as much as she could. Sewing clothes, selling powder, cigarette, becoming soap and hoe agent she did to collect money, because it's impossible for her asking for money to her parents who were also didn't have enough. She never forgot to pray and ask to God for Soekarno's freedom. Even though she sometimes cried at home, all those things Inggit did without any complain [4].

1931 became worst year for Soekarno in Sukamiskin. PNI, the party that he built since first, he raised, and became his hope for Indonesia's independence, came to disunity. Again, Inggit became the one who strengthen him through this struggle. Besides, Inggit also had role as informant for Soekarno and told him about the up to date political situation outside the prison, even though it could threaten her life. She did it through secret codes, she also gave him Al-Quran and religion books to be read. December 29, 1931, with the cut of 2 years, Soekarno released from prison and came back home [4].

After being released, Soekarno did his political activities again. More than 6 months he tried to unite new PNI and Partindo, which are the result of disunity the old PNI, but never succeeded. And as the last step he could take, Soekarno decided to choose between two party. August 1, 1932 Soekarno became member of Partindo branch Bandung. Since that, Soekarno started to move around in Java and came back as "the lion of the podium" through his speeches [1].

Soekarno's political speeches made him arrested again. On August 1, 1933 he was arrested by Dutch police in charge of doing subversive action. Government decided to take assertive action. Soekarno exiled to Ende, East Nusa Tenggara. This incident made Soekarno lost his prestige for the second time. People who usually came and listened to his speech must be changed with exile which far away from applause. This made Soekarno mentally pressed [4]. Hatta in his memoirs said that Soekarno's arrest on July 31, 1933 shook the political air [12], [13].

Unstable psychological condition of Soekarno became inner punch for Inggit. With thorough consideration, Inggit decided to accompany Soekarno to Ende, so did Amsi, Inggit's mother, Omi and their two maids [1]. This showed that Inggit was the real power and companion for Soekarno at that time.

At first, it was hard for Inggit to blend in with people in Ende. But, Inggit got around with by inviting them to talk first. She also sold clothes again there. The family tried to farm but it doesn't work. At the end, their relationship with people in Ende became warmer. It was like a new start for Soekarno and family. Unfortunately, not long after, on October 1935, Inggit had to lose her beloved mother because of unknown ill. Even though Inggit was very sad, she tried to stay strong and strengthen her other beloved ones, Soekarno and Omi, who was also felt very sad because of Amsi's death. Inggit and Soekarno keep sending prays for Amsi [4].

Even though their living in Ende was alright, Soekarno still held big longing to the people who praised him when 
he did his great speech. Besides this longing, Soekarno also got Malaria that made him became thinner and worse. Luckily, government knew about Soekarno's illness. Government decided to move Soekarno and family from Ende to Bengkulu [1]. Inggit never imagined that their movement to Bengkulu became the start of their housewifery's crack.

Their trip to Bengkulu was a very long trip. Soekarno, Inggit, Omi, their maids, and Kartika, a girl who they adopted as daughter in Ende, went there through Surabaya and Jakarta. Inggit also took time to visit families in Bandung [1].

In Bengkulu, Soekarno had good relationship with leader of Muhammadiyah branch Bengkulu, Hasan Din. So did their family. Hasan Din had one and only daughter named Fatmawati. Because she loved to be friend with Omi and didn't want to go home, Fatma stayed at Soekarno's house with his family. Inggit also treated Fatma like her own daughter, the same as Omi and Kartika [4].

As time went by, Inggit felt difference in her husband since Fatma stayed with them. Sometimes, Soekarno treated Fatma better than how he treated Omi and Kartika. But, at that time, Inggit tried to throw away those thinking and trusted her beloved husband [4].

Right on 1939 Omi graduated from vocational school. Inggit and Soekarno decided to send Omi to Taman Siswa in Yogyakarta to continue her study. For almost one month, Inggit accompany Omi to take care of school needs in Yogyakarta by herself. After came back to Bengkulu, Inggit felt something weird in her house [4].

One night, in their room, Soekarno and Inggit had a serious talk. Soekarno said that he wanted to have his own children, one thing that Inggit would never be able to fulfill. Moreover, at that time, Inggit had reached her 50s age. Inggit only responded Soekarno's request by silence. On next talk, Soekarno asked Inggit the same thing. But, Inggit responded it by questioning Soekarno's feeling to Fatma. Unexpectedly, Soekarno insisted to marry Fatma, even though Inggit Inggit didn't want him to have two wives [4].

17 years ago, Inggit felt the same pain when she divorced with Nata Atmadja and became widow in very young age. The same thing happened to her housewifery with Haji Sanusi. Inggit was very disappointed. Fatma, a girl who she used to be prepared the breakfast, praised for her beauty, unexpectedly made her housewifery came to ruin [1].

For Inggit, being not only one in housewifery was a prohibition. But, Soekarno keep insisted to marry Fatma to have his own children. Through lot of consideration, Inggit gave up. She let her beloved to divorce him and marry Fatma who were waiting in Bengkulu. She must allow Soekarno for Indonesia and for Fatma, because from her Soekarno could have children who will continue his step in future. Even though Soekarno left her to marry Fatma, Inggit never had revenge. Inggit did everything sincerely and didn't regret it or ask for compensation. Inggit loved him sincerely, when Soekarno was still her husband, after they divorced and even after Soekarno passed away [8].

\section{CONCLUSION}

Women always hold important role in family, also in development of civilization. Women, as mothers, are the first people who teach children how to live. Women, as wives, are the people who always accompany their husbands, take care of them, and strengthen them on hard times.

The same role was played by Inggit Garnasih during her life with one of important person for Indonesia's independence, Indonesia's first president and proclaimer, Ir. Soekarno.

Inggit played big role during Soekarno's crucial years. 20 years of their togetherness was fulfilled by struggle and sacrifice. Inggit supported her beloved's struggle sincerely and always loved him through many obstacles in life. Inggit helped Soekarno to get up when he was down, to keep his spirit when he was depressed. Inggit had no revenge and no regrets even her story came to sad end. Inggit accompany Soekarno to the gate of glory without tasting the glory itself.

\section{REFERENCES}

[1] R. Nuryanti, Perempuan Dalam Hidup Sukarno: Biografi Inggit Garnasih, Yogyakarta: Penerbit Ombak, 2007.

[2] Hendrasmara, Menelusuri Jejak Marilyn Monroe, Yogyakarta: Grafindo Litera Media, 2005, pp. VI.

[3] A. Matta, Nafas Cinta Sang Kekasih, Sabili: December 2004, pp. 42.

[4] R. Kartahadimadja, Ku Antar Ke Gerbang: Kisah Cinta Ibu Inggit dengan Bung Karno, Jakarta: Penerbit Sinar Harapan, 1981.

[5] J. Legge, Sukarno Biografi Politik, Jakarta: Pijar Fandra Gemilang, 1992 , pp. 35.

[6] A. Setiadi, Soekarno Bapak Bangsa, Yogyakarta: Palapa, 2013, pp. 21.

[7] T. Abdullah, A. Mahasin, and D. Dhakidae, Manusia dalam Kemelut Sejarah, Jakarta: LP3ES, 1978, pp. 20-21.

[8] B. Hering, Soekarno: Arsitek Bangsa, Jakarta: Kompas, 2002, pp. 3.

[9] C. Adams, Sukarno: An Autobiography, New York: The Bobbs-Merril Company, Inc., 1965, pp. 17.

[10] Anonum, Don Juan yang Mahir Bercinta: Kisah Asmara Bung Karno, Jakarta: Tempo, June 10, 2001, pp. 19.

[11] T. A. Hadi, Fajar yang Luka, Bandung, vol. 43, pp. 19, 2000.

[12] B. Hering, Soekarno, Founding Father of Indonesia, Leiden: KITLV Press, 2002, pp.

[13] M. Hatta, Mohammad Hatta Memoir, Jakarta: Tinta Mas, 1985, pp. 388.

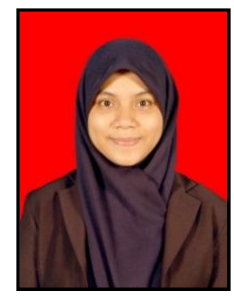

Devina Widya Putri was born in Jakarta, Indonesia on December 20, 1994. Devina is a student in University of Indonesia, Geography major, since 2012. She has interest in environmental and urban management. Inggit Garnasih is her role model of being a woman in life, a wife for husband, and a mother for children. The paper, Inggit Garnasih and Her Big Role as Soekarno's Wife, became her first international publication. 